\title{
NON-TRADITIONAL THREATS TO SECURITY IN THE DISCOURSE OF TAIWAN PRESIDENTS CHEN SHUI- BIAN AND MA YING-JEOU: A DOUBLE-EDGED SWORD
}

\author{
Anna Rudakowska \\ Tamkang University, Department of Global Political Economy, Taiwan \\ Associate Researcher, Vrije Universiteit Brussel Department of Political Science, Belgium \\ e-mail: anna_taiwan@hotmail.com
}

\begin{abstract}
Taiwan's external relations have been mainly examined from the traditional perspective, which sees territorial conquest as the most important problem in the study of international security. This article asks how and why non-traditional security is relevant to Taiwan's foreign policy. In order to answer this question, it examines the articulation of Non-traditional Threats to Security (NTS) and their framing in the discourses of the Taiwan Presidents Chen Shui-bian and Ma Yingjeou. It finds that threats of an economic nature and threats related to pandemics are the most prominent NTS in the island's political rhetoric. This article highlights the opposite processes taking place on the national political stage when the political elites refer to NTS. One the one hand, the discourse about economic threats to security limits Taiwan's participation in global trade. By linking trade to the question of sovereignty, the political labelling of this issue, originally considered to be of an economic nature, translates into protectionist trade policies with respect to China. On the other hand, the new understanding of pandemics as a threat to security opens the door of opportunity for Taiwan's participation in international affairs, as it enables Taiwanese politicians to speak about the island's observer status in the World Trade Organization (WHO) not as a political issue related to the question of sovereignty but as an issue of human security.
\end{abstract}

Keywords: non-traditional threats to security (NTS), Taiwan external relations, Chen Shui-bian, Ma Ying-jeou, cross-Strait relations

\section{INTRODUCTION: BROADENING SECURITY AGENDA IN ASIA AND IN TAIWAN}

Traditionally, security is defined as protection of state sovereignty from military threats posed by other states. This understanding of security has greatly broadened in the post-Cold War period with respect to the nature and the sources 
of threats as well as the objects of security. Observers of the changed international environment after the end of the bipolar world pointed to the significance of threats of a non-military character, not necessarily posed by the states and very often producing consequences reaching far beyond one country, such as environmental degradation, economic crisis, terrorism, pandemic diseases, and consequences of immigration. They proposed the concepts of 'comprehensive security' and 'nontraditional threats' to cover multiple security concerns. Additionally, increasing attention to the consequences of intra-state conflicts and civil wars for individuals in connection with the spread of ideas on human rights and humanitarian intervention has questioned the state-centered approach to security where the nationstate remains the main provider and object of security. In this respect, the idea of 'human security' takes individuals as the central object of security and draws attention to the threats faced by vulnerable groups, such as for example religious and ethnic minorities or the poor and uneducated.

Post-Cold War calls to broaden the concept of security with a range of new issues have resonated also among the Asian political elites and academia. Notions of 'non-traditional', 'comprehensive', or 'cooperative' security gained popularity in Asia particularly after the Asian economic crisis of 1997-98, the spread of the 2003 Severe Acute Respiratory Syndrome (SARS), the Indian Ocean tsunami of 2004, and the earthquake in Japan in 2011. Similarly, the idea of 'human security', which focuses on individuals and communities as a referent object of security, entered the lexicon of Asian politicians as well as civil society actors ${ }^{1}$. However, the degree to which the new notions of security have been embraced by the Asian governments differs from country to country. For example, the Chinese government has adopted the concept of 'comprehensive security' as well as 'non-traditional security', but avoids references to 'human security', ${ }^{2}$ while Japanese politicians frequently refer to 'human security' in their statements and promote this idea internationally. ${ }^{3}$

Taiwan's definition of security has also expanded in the last two decades to encompass much more than the military threat posed by the People's Republic of China (PRC). From the early 1990s on, the Taiwanese administration has acknowledged the transnational nature of new threats to security and recognized the need for international cooperation to overcome them. While the 1992 National Defence Report, except for one short paragraph on 'Disaster Relief and Rescue', is still fully devoted to the 'most direct and most serious threat' to Taiwan exist-

1 M. Alagappa, Asian Security Practices: Material and Ideational Influences, Stanford University Press, Stanford, Calif., 1998; M. Callabero-Anthony, R. Emmers, Understanding the Dynamics of Securitizing Non-Traditional Security, in: Non-traditional Security in Asia, (eds.) M. Callabero-Anthony, R. Emmers, A. Acharya, Ashgate Publishing Company, Burlington 2006, p. 1-12.

2 G.G. Wu, China's Challenges to Human Security: Foreign Relations and Global Implications, Routledge, London 2013, p. 17.

3 J. Kotsopoulos, European Policy Centre Issue 48, „A Human Security Agenda for Europe", June 2006. 
ence in the form of the 'Chicoms [the Chinese Communists'] use of force against Taiwan', ${ }^{4}$ the subsequent report already recognizes the 'new international order in the post-cold war era', anticipates the 'growing influence of economy and trade as well as the rise of regional consciousness' as the characteristics of future global order, and identifies economic competition as a potential threat to the region. ${ }^{5}$ By the time of the 2000 report, Taiwan had fully embraced the notion of non-traditional threats as well as human security, as the report issued that year points to the number of transnational threats. It recognizes the multiple dimensions of security - political, military, diplomatic, economic, scientific, technological and cultural, environmental and informational - and proposes that security 'no longer is confined to any given nation's sovereignty issues; the common security of the entire human society is also viewed as involved'. ${ }^{6}$ All the following editions of the report evaluate non-traditional threats as highly relevant for the national security. ${ }^{?}$ Similarly, the National Security Reports released by the presidents' administration since 2006 propose the broad concept of national security encompassing, besides military security, economic, financial, information and energy dimensions, land conservation issues, epidemic prevention, and questions related to ethnicity and national identity. ${ }^{8}$

Even though the references to non-traditional security figure prominently in the Taiwanese political discourse, the security of the Republic of China (ROC) has been examined mostly from the traditional perspective, which sees territorial conquest as the most important problem in the study of international security. Taking into account the situation in the Taiwan Strait, this approach should not be surprising. Chinese military power has always been perceived as the main threat to the security of the Taiwanese people, since Beijing has never renounced the use of military force against Taipei. Taiwan is almost absent from the studies on non-traditional security for two additional reasons. First, it is not seen as an actor in global security in the same way as, for example, China, which due to the country's size, population, economic strength and growing influence on interna-

${ }^{4}$ Ministry of National Defence, National Defence Report of the Republic of China, Li Ming Cultural Enterprise Co., Taipei 1992, p. 4.

5 Ministry of National Defence, National Defence Report of the Republic of China, Li Ming Cultural Enterprise Co., Taipei, 1994, p. 1. 1992 'Defence White Paper of the Republic of China on Taiwan' was the first from the series of Defence Reports edited biennially following the 19931994 issue. In: Ibidem, p. 27.

6 Ministry of National Defence, National Defence Report of the Republic of China, Li Ming Cultural Enterprise Co., Taipei 2000, p. 5-10.

7 For example, the 2011 Report addresses the concept of comprehensive security and points to unconventional and transnational security issues, such as natural disasters, competition over maritime rights, energy exploration, food production, and water resources, as well as terrorist attaches. In: Ministry of National Defence, National Defence Report of the Republic of China, Li Ming Cultural Enterprise Co., Taipei 2011, p. 25-26.

8 National Security Council, National Security Report, National Security Council, Taipei 2006, p. 39. 
tional affairs is believed to create a great impact on global climate, environment, energy, food, pandemics, etc. ${ }^{9}$ To be sure, the Taiwanese demographic developments will not influence the global food supply chains in the foreseeable future in any way comparable to China. Adding to this, Taiwan's exclusion from the most international fora, particularly the intergovernmental organizations (IGOs), diminishes its voice in the global affairs as well as limits its potential contribution to fight against transnational threats. Second, Taiwan has been omitted from the analyses of non-traditional security in Southeast Asia, because a great number of such studies focuses on the member states of the Association of South-East Asian Nations (ASEAN) of which Taiwan is not a part.

This article asks how and why non-traditional security is relevant to Taiwan's foreign relations. In order to answer this question, it examines the articulation of Non-traditional Threats to Security (NTS) in the discourses of the ROC Presidents Chen Shui-bian and Ma Ying-jeou. It defines non-traditional threats as nonmilitary in nature, which means that they cannot be linked directly to the military actions of the other state. They may be produced by other states and/or non-state actors or phenomena and imperil the security of a state and/or individuals. Examples of NTS may include environmental degradation, health and demographic (migration and ageing) challenges, terrorism, transnational organized crime, piracy, and economic crisis.

The presence of NTS in the discourse of Taiwanese officials should be understood within the broader context of Taiwan's specific relations with China and the island's resulting ambiguous status in international relations. One has to remember the difficult task Taipei faces while striving to stay connected to the world and make its voice heard. First, Taiwanese elites need to act very cautiously so as not to upset their big neighbour, as Beijing may interpret any Taiwanese move on the international stage as a threat to national interests. ${ }^{10}$ Second, Taiwanese political elites, while being cautious about Chinese interests, also need to respond to the preferences of their own citizens, the majority of whom see maintaining international respect and expanding the island's international space as crucial political issues. ${ }^{11}$

In this context, the concept of NTS provides a lens through which to explore Taipei's way of dealing on the one hand with pressures of globalization, including challenges and opportunities stemming from China's rising power and increasingly international role, and on the other hand, with its own specific status in international affairs, which to a certain degree means international isolation. This article will contribute to the understanding of Chen's and Ma's rhetoric on non-

${ }^{9}$ G.G. Wu, op. cit., p. 11.

${ }^{10}$ As for example, to avoid the situation similar to that of 1995 when Beijing interpreted Lee Teng-hui's visit to the US as undermining the status quo and responded with missile tests.

${ }^{11}$ P.H. Gries, J. Su, Taiwanese Views of China and the World: Party Identification, Ethnicity, and Cross-Strait Relations, "Japanese Journal of Political Science" 2013, 14 (1), p. 73-96, 93. 
traditional threats to Taiwan's security in order to advance comprehension of the concept of NTS and the practice of Taiwan's relations with the world.

\section{THEORY AND METHODOLOGY}

This study is based on the constructivist belief that security is a social construct, which is not timeless, but constantly transforming through negotiation and contestation. Threats do not exist objectively, but are created discursively. As David Campbell explains: 'Danger is not an objective condition. It (sic) is not a thing which exists independently of those to whom it may become a threat' and develops his argument: 'Nothing is a risk in itself; there is not risk in reality. But on the other hand, anything can be a risk; it all depends on how one analyses the danger, considers the event.. ${ }^{12}$ Drawing on constructivists' insights concerning our knowledge about the world, this study treats various approaches to security as well as threats to security as descriptions of reality with particular consequences for Taiwanese foreign policies. It is not interested in the 'true' or 'false' value of the articulations of NTS or the 'real' motives of the politicians standing behind their references to these threats, but rather in the very construction of arguments pertaining to NTS and their application in the political debates to justify certain actions and condemn others.

The issues are introduced to the realm of politics as threats for the purpose of an argumentative strategy. Within argumentation theory, threats constitute a part of argumentation scheme based on the explicit or inferable premise where political action or decision, which bears threatening consequences, should not be performed, or someone should do something against it. ${ }^{13}$ For this reason, the inclusion of this argumentative scheme referring to a threat may have consequences for political decisions and actions. Therefore, the analysis of NTS in a discourse will provide the answer about the relevance of the non-traditional security to Taiwan's foreign relations. ${ }^{14}$

Within the framework of the main research problem concerning the relevance of the non-traditional security to Taiwan's foreign relations, this study asks the

${ }^{12}$ D. Campbell, Writing Security: United States Foreign Policy and the Politics of Identity, University of Minnesota Press, Minneapolis 1992, p. 1.

${ }^{13}$ R. Wodak, The Discourse-historical approach, in: Methods of Critical Discourse Analysis, (eds.) R. Wodak, M. Meyer, New Delhi, Thousand Oaks, London 2001, p. 63-94, 74-75.

${ }^{14}$ This study is interested in the act of labelling issues as 'threats to security', yet it does not draw on the securitization approach. It assumes that defining issues as 'threatening' to security does not necessarily have to lead to their 'securitization' characterized by urgency or secrecy in dealing with them or to the so-called 'panic politics' opposed to 'normal politics', involving democratic deliberation and the rule of law (Buzan et al. 1998:34) and focuses on the application of existential threats in discourse for the purpose of various argumentative strategies, for example, to justify actions, ascribe responsibility, express support, make demands, etc. 
following questions: What non-traditional threats dominate the discourse of Taiwan Presidents Chen and Ma? How are these threats framed, i.e. what issues, decisions, policies and strategies are they linked to? How have the perceptions of non-traditional threats come into being and evolve? How have the presidents dealt with these threats, and were their actions limited or enabled by NTS? How significant is the space for the Taiwanese presidents in positioning various actors and issues as threats? How congruent are the approaches to NTS with the main security threat to Taiwan? How are the linkages between traditional and nontraditional security created, and what are the overlaps? In an attempt to answer these questions, the study will discern the main argumentative schemes articulated by the Taiwanese presidents.

Given that the statements of Taiwanese presidents are perceived as representative of preferences prevailing in Taiwan, this analysis focuses on their argumentative practices. As Jonathan Sullivan and Will Lowe argue, the public statements of the Taiwanese presidents are 'interpreted as an indicator of Taiwan's underlying preferences and policy positions' and are received with great attention. ${ }^{15}$ Additionally, due to the absence of institutionalized channels for communication between the presidents on the both sides of the Strait, the pronouncements from Taipei may produce consequences in reality, even leading to tensions with Beijing or the USA. ${ }^{16}$

Saying this, from the constructivist perspective, various actors compete to define threats to security as to provide grounds for new policies. This designation of meaning is beyond the ability of an individual, even one as powerful as a president. It represents a collective process involving multiple stakeholders shaping the reservoir of acceptable threat representations that influence the everyday practices of Taiwan's external relations. In Taiwan, the politicians have been accountable for their actions ever since democratic transition started in the 1980s. Political power was handed to civil society and various interest groups contributed to the creation of political discourse. Given that security is a site of contestation for meaning, the president's speeches respond to former articulations, are presented with a certain audience in mind and with anticipated consequences of the utter-

15 J. Sullivan, W. Lowe, Chen Shui-bian: On Independence, "China Quarterly" 2010(203), p. 619-638, 621 .

16 The so-called 'One China, respective interpretations' (OCRI) consensus may demonstrate the performative function of the words in the cross-Strait relations. Since 1949, Taipei and Beijing claimed to be solely legitimate governments of China and denied the other side the authority. When the talks between China and Mainland began in the early 1990s, both sides made attempts to avoid mentioning of this point of disagreement. Still, it was coming up and obstructing discussion and progress in cooperation even in practical matters, such as document authentication or tracing registered mail. Finally, Taipei and Beijing agreed to the interpretation, which was acceptable for both sides as well as their domestic audiences and stated that 'The two sides of the Taiwan Strait uphold the One China Principle, but the interpretations of the two sides are different (...) Taiwan is a part of China, but the mainland is also a part of China'. After: C. Su, Taiwan's Relations with Mainland China: A Tail Wagging Two Dogs, Routledge, London, New York 2009, p. 12-13. 
ances for the future. Therefore, the utterances of presidents will be analysed within the broader context of opinions circulating in the society.

The analysed texts come from the website of the Office of the President (www. president.gov.tw), where speeches, decrees, press releases, meetings' memoranda and other texts produced by the Taiwanese presidents and vice-presidents from 1 January 1993 until the present are gathered under the heading 新聞稿 (xinwen gao - press release). This database allows for searches according to date and keyword criteria both within the title and body text of the document. This study focused on texts produced by President Chen during his first and second term in office from 20 May 2000 until 19 May 2008 and President Ma during his first and second term in office from 20 May 2008 until 20 October 2015 (when the analysis was conducted), but also reaches to the texts produced by President Lee Teng-hui to demonstrate the formation and evolution of important discourses. Additionally, the arguments of the vice-president and other political actors, various official publications of the Taiwanese administration, including 'Important Documents on the Government's Mainland Policy', 'National Defence Reports', 'National Security Reports' and the literature on cross-Strait relations and Taiwan's external relations provide background information about the discourses on NTS circulating in the Taiwanese society.

\section{THE NON-TRADITIONAL THREATS IN TAIWAN'S POLITICAL DISCOURSE}

Three types of NTS stand out in Taiwanese political rhetoric during the presidency of Chen Shui-bian and Ma Ying-jeou: economic threats, threats of pandemics, and natural disasters. This article examines the threats arising from the spread of pandemics and threats of an economic nature, leaving out the topic of natural disasters in Taiwan, as the presidents have presented them mainly as a domestic issue rather than in the context of external relations.

\section{THE RELEVANCE OF THE ECONOMIC THREAT TO TAIWAN'S FOREIGN POLICY}

The most common NTS in Taiwanese political discourse are of an economic nature. These threats are described as emanating from economic exchange with China and serve as an element of the argumentative scheme justifying restrictions on cross-Strait relations. The following examines the argumentative schemes constructed around the topic of economic threat, namely how they came into being and the decisions and actions justified by them - first in the speeches of Chen Shui-bian and moving toward the rhetoric of his successor Ma Ying-jeou. 
1) Taiwanese investors in the Mainland as a threat to Taiwan's political interests. The argument is based on the following conditions: if the Taiwanese businesspeople benefit from cross-Strait economic exchange, they are likely to push for more liberal trade policies with China. Therefore the investors, who constitute a comparatively powerful force in domestic politics, will provide an effective channel through which the Mainland can influence Taiwan's politics. Taiwanese politicians as well as political activists have invoked this strategy in order to legitimize a number of restrictive policies in relations with China, such as, for example, a ban on the so-called 'three links' ${ }^{17}$ President Lee already in 1996 justified the restrictions on economic ties with the Mainland with reference to the Beijing's strategy of using civil society and particularly business people to compel Taiwanese politicians to yield to the Mainland's demands in a following manner:

Nowadays, [the PRC] deliberately adopted the 'cooling off treatment' [implying less tensions] to create pressure on our government by means of 'using people to force the officials' and 'using businesspeople to encircle the government', in an attempt to increase anxiety in the all circles of our society. In view of this situation, we must uphold the "no haste, be patient' general rule to deal with the current cross-Strait relations. ${ }^{18}$

In this speech, Lee referred to the PRC's strategy declared in the 1979 'Temporary Regulations Regarding Opening Trade with Taiwan' according to which exchange with Taiwan was seen as a 'special form of trade', while the economic relations, as the PRC's President Yang Shangkun stated in 1990, were at the service of politics. ${ }^{19}$ President Chen, notwithstanding his initial advocacy of more open economic exchange across the Strait than the previous government and the introduction of a number of policies relaxing the rules for trade and investment, frequently referred to this argumentative scheme to justify various decisions regarding China, including the legitimization of the ban on the 'three links'. For instance, he criticized demands of the business community to open direct communication across the Strait, arguing that even though the direct links will benefit businesspeople, in general, the change will have detrimental consequences to the 23 million Taiwanese people, as it will be harmful for Taiwan's national security:

${ }^{17}$ The three links (三通 san tong) refer to direct contacts across the Strait via the postal route, trade and communication, including maritime and air communication. Despite the flourishing trade and investment across the Strait since the late 1980s, Taiwan banned all three types of direct contacts with the PRC. In a consequence, trade from Taiwan to China had to pass via intermediate locations, such as Hong Kong. Despite the demands of the business circles to lift this restriction, it remained in place until Ma's term in office.

${ }^{18}$ Lee Teng-hui, 總統參加第三屆全國經營者大會 President Participated in the Third National Conference of_Managers, Office of the President, 14.09.1996. Author added the comments in square brackets, while the parts in quotation marks are as in original.

${ }^{19}$ C.C. Chen, Useful Adversaries: How to Understand the Political Economy of Cross-Strait Security, in: New Thinking about the Taiwan Issue: Theoretical Insights into its Origins, Dynamics and Prospects, (eds.) J.F. Blanchard, D.V. Hickey, Routledge, Abingdon 2012, p. 48-70, 50. 
Businessmen consider solely how the three links can save travel expenses of two or three billions per year and regard the three links as a panacea to solve the problems of Taiwanese economy, but totally ignore the huge impact of the establishment of the direct contacts on 23 million compatriots in Taiwan, and significant harm caused by a largescale capital outflow. ${ }^{20}$

2) Economic dependence as a source of Taiwan's vulnerability to the PRC's economic coercion. The logic of this scheme is as follows: Taiwanese investment in China and trade, mainly due to the asymmetric nature of cross-Strait economic relations, leads to dependency of Taiwanese companies and economy on the Mainland. This in turn increases the adversary's bargaining leverage over Taiwan. In order to prove the existence of increasing dependency on the PRC, supporters of this opinion refer to statistical data on Taiwan's exports and investment in the Mainland, which have dramatically risen since the late 1980s. President Lee applied this argumentative scheme. Lee's warnings against the possible consequences of economic dependence on the Mainland for Taiwan's security served as a rationale for his 'no haste, be patient' (戒急用忍 jieji yongren) policy. $\mathrm{He}$ claimed that this policy was necessary as long as the adversary was thinking about cross-Strait relations in terms of struggle, while Taiwan looked at the relationship as a win-win situation. ${ }^{21}$

President Chen replaced the policy of 'no haste, be patient' in 2001 with seemingly less restrictive strategy of 'active opening and effective management' (積極開放、有效管理 jiji kaifang youxiao guanli). Indeed, during his term in office, some restrictions on cross-Strait economic exchange were lifted, including those on investment or the establishment of the so-called 'mini direct links', which since 2001 have allowed people to travel directly to the islands of Jinmen and Xiamen on the other side of the Taiwan Strait. Yet despite Chen's initial championing of economic liberalization across the Strait, in the following years only limited progress towards this goal had been made. As Chi Su explained in his study on Taiwan's Relations with China between 1987 and 2004, the 'effective management' in practice meant control and restrictions on cross-Strait exchanges for the purpose of national security. ${ }^{22}$ The economic dependence argument became popular among politicians who wanted to see the cross-Strait exchanges restricted and in general resonated with the general Democratic Progressive Party (DPP) ideology underlining the need to protect and preserve the Taiwanese nation in its relations with China. This approach in connection with the argument about

${ }^{20}$ Chen Shui-bian, 總統府舉行中樞紀念國父誕辰、慶祝中華文化復興節大會典禮 President Held the Ceremony Commemorating the Birth of Founding Father of the Republic to Celebrate his Ideas and the Chinese Cultural Renaissance, Office of the President, 12.11.2002.

${ }^{21}$ Lee Teng-hui, 總統向國家策略研究班學員講話 President Delivers Speech to the Students at the Seminar on the National Strategy, Office of the President, 08.09.1998.

${ }^{22}$ C. Su, Taiwan's Relations with Mainland China: a Tail Wagging two Dogs, Routledge, London; New York 2008, p. 181. 
economic dependence at the economic policy level may easily translate into restrictive policies with the goal of defending Taiwan's sovereignty.

3) Detrimental consequences of the outflow of resources and people for Taiwan's economy. The advocates of this argument point that the outflow of capital, labour, and know-how to the Mainland will take away the resources necessary for the national development and undermine the growth prospects of the island's economy. Moreover, there is a widespread anxiety about the loss of jobs as a result of relocating Taiwanese companies to the Mainland. Taiwanese political elites have referred to this discourse to legitimize policies encouraging Taiwanese businesspeople to invest in the countries of Southeast Asia rather than in China. As the example of policies justified in this manner may serve Lee's 1994 Go South (南向政策 nanxiang zhengce) policy, also promoted by President Chen in 2002 and 'go southward policy' announced in 2015 by the presidential candidate Tsai Ing-wen to diversify Taiwan's trade. Additionally, this argumentative scheme had been applied with respect to policies aiming to keep the businesspeople in Taiwan instead of investing in China, such as Lee's 1996 plan to create the Asia-Pacific Operation Centre in Taiwan (亞太 營運中心 Yatai Yingyun Zhongxin). President Lee explained that one of the aims of this centre was to make it possible for domestic companies to keep their roots growing in Taiwan. ${ }^{23}$ Similarly, his policy of 'no haste, be patient' was established to diminish the capital outflow to China and in general to manage and restrain the pace of economic exchange with the PRC, as it imposed direct bans on investment and trade. President Chen pointed to the significant harm caused by the outflow of capital from Taiwan to China and linked China's rise to increasing unemployment in Taiwan. Moreover, Taiwanese society had become anxious about the outflow of resources and skills. For example, protestors against the government's decision to lift the ban on semiconductor investment in China in 2002, in a similar manner to President Lee, called for businesspeople to 'keep roots in Taiwan'. ${ }^{24}$

4) China's rapid economic growth as a threat to Taiwan. The supporters of this argument remind us that Beijing converts economic rise into military strength, which is mostly aimed against Taiwan. Analogous narrative underscoring the 'China threat' to other countries gained in popularity in the West after the end of

${ }^{23}$ 國內企業能根留台灣 (guonei qiye neng gen liu Taiwan) in: Lee Teng-hui, 總統接見台 灣商會聯合總會第二屆會員代表大會代表 President Delivers Speech to the Second Congress of Representatives of the Taiwan Chamber of Commerce, 10.09.1996. For more information on the positive incentives provided by the Taiwanese government to divert Taiwanese businesspeople from investing in China, see: S.L. Kastner, Political Conflict and Economic Interdependence across the Taiwan Strait and Beyond, Stanford University Press, Calif, Stanford 2009, p. 58.

${ }^{24}$ Lin Mei-chun, 1,000 Protest Relaxation of Wafer Rules, „Taipei Times”, 10.03.2002, 3, available at: http://www.taipeitimes.com/News/taiwan/archives/2002/03/10/0000127081, access: 28.10.2015. 
the Cold War. ${ }^{25}$ In Taiwan, this rhetoric on economic threat can be traced back to President Lee, who suggested that the economic growth of China might be menacing not only to Taiwan, but also to the whole Asia-Pacific region. ${ }^{26}$ President Chen pointed to several elements of this discourse, including the military and economic dimension of China's threat and the uncertainty created by China's rise for third-world countries, global order, and for Chinese stability as well as democracy as a referent object of insecurity in relation to this threat. ${ }^{27}$ In order to legitimize the restrictive policies on economic exchange with China, Chen frequently stressed that Chinese economic growth indirectly threatened Taiwan's security as Beijing reinvested its economic gain into growth and modernization of the army. ${ }^{28}$ Therefore, he reinforced the discourse about Chinese economic threat to a vulnerable Taiwan, which, as a result, became well established before 2008 .

At the same time, Lee as well as Chen both referred to the competing neoliberalist narratives about free trade and globalization. President Chen, in his first year in office, publicly promoted lifting a number of the restrictions on economic exchange with China, including the reestablishment of the three links, explaining that direct contacts across the Strait are natural in times of global economic interdependence and are consistent with Taiwan's imminent membership in the WTO. ${ }^{29}$ He advocated the improvement of relations with China built on the foundation of economic ties. Similar to his predecessor, he proposed gradual 'normalization' (正常化 zhengchanghua) of overall relations with China, which would commence from the economic exchange and in time spill over into the other areas, including politics. ${ }^{30}$ Chen made clear that this strategy was based on Lee's 'integration theory' (統合論 tonghe lun).$^{31}$ This normalization of relations by means of the strengthening of economic links, in the opinion of Lee and Chen, was supposed to serve as a springboard for Taiwan's new role in Asia's economic networks, where Taiwan was to serve as a regional operation centre, hub or the window for economic contacts between China and the other countries. This contestation between

${ }^{25}$ W.Q. Song, Securitization of the "China Threat" Discourse: A Poststructuralist Account, „The China Review” 2015, (15/1), p. 145-169.

${ }^{26}$ Lee Teng-hui, 總統先生應邀在第五屆「亞洲展望」研討會致詞 President Delivers Speech at the Fifth Seminar „Vision Asia”, 19.11.1993.

${ }^{27}$ Chen Shui-bian, 總統拜會巴拉圭共和國國會並演講 President Pays Visit to the Congress of the Republic of Paraguay and Delivers a Speech, Office of the President, 31.05.2001.

${ }^{28}$ Chen Shui-bian, 總統參加「國軍九十年高級幹部研習會」致詞 President Delivers Speech at the „Seminar for the 90 Years of National Army High-Ranking Cadres," Office of the President, 13.02.2001.

${ }^{29}$ Chen Shui-bian, 總統發表跨世紀談話 President Delivers a Speech for a New Century, Office of the President, 31.12.2000.

${ }^{30}$ Ibidem and Chen Shui-bian, 總統接見第井一屆中美當代中國研討會外賓 President Received the Foreign Guests Participating in the 31st Session of the Sino-US Seminar on Contemporary China, Office of the President, 04.06.2002.

${ }^{31}$ Chen Shui-bian, 總統參加美國華府「外交關係協會視訊會議」President Participates in the Video Conference of the United States, Washington „Council on Foreign Relations” 17.05.2001. 
the competing discourses in the area of economics - one on the economic threat caused by cross-Strait exchange and the other on free trade as a prerequisite for Taiwan's economic development, indicate the lack of agreement in Taiwan with respect to the economic policies towards its neighbour.

President Ma Ying-jeou's rhetoric on economic threats should be analysed within the context of these competing discourses, which, on the one hand, picture Taiwan as exposed to an economic threat from Mainland China and on the other advocate the improvement of relations with China. Ma took office from Chen in 2008 with a mandate to revive the island's economy and improve cross-Strait relations. ${ }^{32}$ In stark contrast to President Chen Shui-bian, he embarked on a policy of rapprochement with China through various channels including party-to-party, Track Two, and semi-official interactions as well as softening the tone in Taiwan's efforts to participate in international organizations (IOs). His approach to relations with China led to signing economic and technical agreements, including the establishment of the three direct links between the two sides, the opening of Taiwan to Chinese tourists and investors, and signing of the Economic Cooperation Framework Agreement (ECFA) in June 2010. Yet the talks on transportation routes and signing of ECFA constituted serious points of disagreement between the DPP and Ma's Administration and aroused great controversy in society. This controversy reached its highest point during the Sunflower Student Movement in March and April 2014. The protestors opposed the ratification of the Cross-Strait Service Trade Agreement (CSSTA) liberalizing trade in services across the Strait. The opposition to Ma's cross-Strait economic policies applied the narratives created before 2008 about Taiwan's vulnerability in the face of economic threat from China, which was reinforced by a powerful and internationally popular discourse about the 'China threat'. According to Tsai Ing-wen, a critic of ECFA and the DPP presidential candidate for 2016, this trade agreement would make '(...) Taiwan lose its independence in cross-Strait relations and become a Chinese parasite'. ${ }^{33}$

Indeed, Ma frequently had to defend his cross-Strait economic policies against the perception of economic relations with China as a threat to Taiwan's security. He referred to statistical data to demonstrate that the problem of dependence on the Mainland was not created during his term in office, but by previous governments. Moreover, in a manner similar to his predecessors' Go South policy, Ma presented himself as an advocate of the diversification of Taiwan's trade. In response to a BBC reporter, who linked the topic of Taiwan's trade with Mainland China to the security threat, President Ma stressed that since his administration had been in power, Taiwan had 'actually reduced dependence on the Mainland compared to the previous administration. We [this administration/Taiwan] have

32 J. Sullivan, Taiwan's 2012 Presidential Election, „Political Studies Review”, 2013 (11), p. 65-74.

${ }^{33}$ Bloomberg Business, „Taiwan President and Opposition Debate”, 2010, 4, URL: <http:// www.businessweek.com/ap/financialnews/D9FA3LH80.htm> (access: 06.12.2015). 
diversified our markets, as a result of which trade dependence on the Mainland has not increased, but, in fact, declined slightly'. ${ }^{34}$ In other places, the president underscored the increase in exports to the United States, Southeast Asia, Europe, and Japan to substantiate his claim about the increase in trade with partners other than China after the signing of ECFA. ${ }^{35}$

However, since statistical data and policies of trade diversification did not provide a sufficient response for the critics of ECFA and other agreements with China, Ma applied additional argumentative strategies to justify deepening economic ties with Beijing. First, he recalled the popular discourses on international economic relations dominated largely by the neoliberalist agenda to claim that it is in the best interest of Taiwan to promote free trade. Examples of this argumentative strategy may serve Ma's remarks in his 2008 inaugural address and 2011 press conference.

Islands like Taiwan flourish in an open economy and wither in a closed one. This has been true throughout history. Therefore, we must open up and deregulate the economy to unleash the vitality of the private sector. This will strengthen Taiwan's comparative advantage'. ${ }^{36}$

'Looking at Taiwan's developmental history, we can see that liberalization has always brought prosperity, while shutting ourselves off from others has led to decline. Not long ago, Taiwan shut itself off from the rest of the world for a period of time and missed opportunities to participate in the economic integration of the Asia-Pacific region' ${ }^{37}$

Moreover, President Ma denoted protectionism as a threat, and as a source of evidence for this claim, he evoked the report of the WTO Secretary-General Pascal Lamy, who pointed to the 'abuse of protectionism' as a factor which would slow down recovery after the economic crisis. ${ }^{38}$

Since our country joined the WTO in 2002, it is committed to the development of the multilateral trading system, and the outbreak of the global financial crisis last year in November was a huge challenge for the multilateral trading system, including the threat of protectionism imminent with the development of the crisis. According to the second

${ }^{34} \mathrm{Ma}$ Ying-jeou, 總統接受「英國廣播公司」（B B C ）專訪 President Ma Interviewed by BBC, Office of the President, 27.07.2015.

${ }^{35}$ Ma Ying-jeou, 總統接受「英國廣播公司」電視新聞頻道專訪相關答問全文 The Full Transcript of the President's Interview with the „British Broadcasting Corporation” TV News Channel, Office of the President, 15.06.2011.

${ }^{36}$ Ma Ying-jeou, 中華民國第12任總統馬英九先生就職演說 Inaugural Speech of the 12th President of the Republic of China, Office of the President, 20.05.2008.

${ }^{37}$ Ma Ying-jeou, Transgenerational Justice: Sovereignty, Human Rights, and Environmental Rights, Press Conference at the National University of Tainan, 19.05.2011, in: President Ma's Speeches and Remarks - On ROC's Mainland Policy and the Future of the Country, Mainland Affairs Council, Executive Yuan, Republic of China, Taipei, August 2011, p. 8.

${ }^{38} \mathrm{Ma}$ Ying-jeou, 總統出席2009年「WTO的未來」國際學術研討會開幕式 President Attends the Opening Ceremony of the 2009 International Symposium on the „Future of the WTO”, Office of the President, 24.05.2009. 
report by WTO Secretary-General Pascal Lamy on the "Financial and Economic crisis and Trade-related Development" issued on 14 April this year, the WTO member states, in response to the global financial crisis and to maintain national economic growth, inevitably will take measures to stimulate the economy, but it is also possible that they will also abuse the trade remedies for protectionist purposes. The recent statistics for the period from 1 July to 31 December this year, show the increase of $17 \%$ in the number of new anti-dumping investigations in comparison with a previous year. ${ }^{39}$

In the same speech, President Ma applied the topic of responsibility to argue that Taiwan, as a member of the WTO, 'is committed to the development of the multilateral trading system'; therefore it is obliged to promote liberal trade policies. In 2014, he recalled the theme of responsibility again as one of the rationales for signing the trade in services agreement (CSSTA) ${ }^{40}$

Second, Ma echoed the discourse about the globalizing tendencies in the economy, where reliance on other countries in trade is unavoidable, to suggest that Taiwan's dependence on the Mainland is not an extraordinary phenomenon but rather a natural consequence of interconnectedness between the economies around the world. In an interview with the BBC, he claimed that Taiwan couldn't avoid 'a certain degree of dependence on the Mainland'. ${ }^{41}$

Third, President Ma depicted the improvement of economic relations with China as a prerequisite for the revitalization of economic relations with the other countries and the only way to avoid Taiwan's isolation on the international stage. He also warned that if Taiwan's main trade partners, such as the US, EU or Singapore, do not observe significant progress in the cross-Strait economic and trade relations, they might be unwilling to tighten cooperation with Taiwan. He cited the 'unanimous voice of foreign businesspeople' who do not come to Taiwan for the local market but want to take advantage of the Taiwanese market as a spring board for developing their business across the region. ${ }^{42}$ The two citations from Ma's speeches provide examples of this argumentative scheme.

I believe that the 'normalization' of the cross-Strait economic and trade relations will be conducive to improving relations with 'ASEAN' countries. ${ }^{43}$

We have to improve economic and trade relations with the Mainland, so that, at the same time, the other countries are willing to negotiate similar arrangements with us; the reason behind this is that many countries follow this logic. That is, when the Mainland

\section{${ }^{39}$ Ibidem.}

${ }^{40}$ Ma Ying-jeou, 總統接受美國《富比士》雜誌專訪 President Ma Interviewed by Forbes Magazine, Office of the President, 26.06.2014.

${ }^{41}$ Ma Ying-jeou, op.cit., 27.07.2015.

${ }^{42}$ Ma Ying-jeou 總統訪視外交部並闡述「活路外交」的理念與策略 President Ma visits the Ministry of Foreign Affairs and Elaborates on the Concept and Strategy of „Flexible Diplomacy", 04.08.2008.

${ }^{43}$ Ma Ying-jeou, 總統副總統與國際媒體茶敘 Tea Reception of the International Media by President and Vice-President, Office of the President, 21.05.2008. 
and Taiwan improve relations, these countries will ask, 'Mainland China is willing to do that, why should we refuse it?'44

Ma's predecessor Chen also discussed the marginalization of Taiwan on the international stage. Yet Chen's references to the narrative about marginalization were made with the goal of blaming China for this course of events. Ma changed strategy and instead of blaming China, depicted tightening of cross-Strait trade ties as an opportunity to improve economic relations with the rest of the world, avoid marginalization and boost Taiwan's economic performance. Additionally, he created a sense of urgency to the signing of trade deals with China by describing Taiwan as 'lagging behind' other countries, which had already finalized the agreements with China or are in the process of negotiations, such as Korea, ${ }^{45}$ or suggesting that '[i]f we disregard what's going on in the world, the world is not going to wait for Taiwan. ${ }^{46}$

President Ma framed his policies expanding exchange across the Strait with reference to these three discourses - on the liberally inspired narratives promoting free trade, narratives on globalization and economic interdependence, and on the threat of marginalization - in order to remove China's economic threat from the picture and to underscore the international economic and political rationale for cooperation. Yet as the discourse on the 'China threat' to Taiwan's security was too powerful to be neglected, Ma had no choice but to incorporate it into his rhetoric. Therefore he amitted that China constitutes the greatest threat to Taiwan's security and suppresses Taipei's international space. ${ }^{47}$ Nonetheless, he also claimed that thanks to the efforts of his administration and implementation of new policies, the danger of military confrontation across the Strait had significantly decreased since the year 2008, being the year when he took power. ${ }^{48}$ Additionally, he frequently depicted China as 'not only a threat, but also an opportunity' and stated that the goal of the government in Taipei should be to "minimize the threat and maximize the opportunity'. ${ }^{49}$ This in turn allowed Ma to claim success for his cross-Strait

${ }^{44} \mathrm{Ma}$ Ying-jeou, op.cit., 15.06.2011; See also: Ma Ying-jeou，總統主持「中華民國建 國98年國慶典禮」President Ma Ying-jeou's National Day Address, Office of the President, 10.10.2009.

${ }^{45}$ Facing the threat of the free trade agreement between the Mainland and Korea, we must accelerate the pace of international economic and trade integration to create a better business environment for the industry. In: Ma Ying-jeou, 總統接見第8屆「國家卓越成就獎」暨第32屆 $「$ 國家傑出經理獎」得獎人 President Met with the Winners of the 8th „National Distinguished Accomplishment Award” and 32nd „National Manager Excellence Award”, 09.01.2015.

${ }^{46}$ Ma Ying-jeou, President Ma Meets US Department of State's Principal Deputy Assistant Secretary for Bureau of Economic and Business Affairs Kurt Tong (in English), Office of the President, 21.11.2014.

${ }^{47}$ Ma Ying-jeou, 總統「就職三週年記者會」President Ma Holds Press Conference to Mark the Third Anniversary of his Inauguration, Office of the President, 19.05.2011.

${ }^{48}$ Ma Ying-jeou, op.cit., 27.07.2015.

${ }^{49}$ Ma Ying-jeou, op. cit., 21.05.2008; Ma Ying-jeou, 總統主持97年三軍五校院聯合畢業典 禮 President Chaired the 2008 Joint Graduation Ceremony of Triservice Armed Forces from Five 
policy aimed at 'minimizing the threat' and to propose liberal economic policies towards the Mainland to 'maximize benefits' ${ }^{50}$ The conflicting discourses about China in Ma's speeches testify that the polarization of society with respect to the economic relations with China, prevalent already in times of Lee and Chen, became rampant during Ma's presidency.

\section{PANDEMICS AS NON-TRADITIONAL THREAT TO SECURITY IN TAIWANESE POLITICAL DISCOURSE}

Pandemics challenge the well-being or even the very survival of people, and as such are framed as a threat to security. They are different from traditional military threat in three respects. First, they are perceived as belonging to the sphere of low politics, since, in opposition to the issues of high-politics, such as military threat, they do not endanger the very survival of the state. ${ }^{51}$ Second, they are considered as an issue of human security instead of national security, since they challenge the well-being or even survival of individuals and not necessarily of states. The third difference is related to the phenomenon of globalization. Given that diseases are no longer contained by natural or manmade borders of states, they have been included among global problems that require global response, coordination, and cooperation. ${ }^{52}$

In 2003, the outbreak of SARS (Severe Acute Respiratory Syndrome) hit Taiwan severely. Afterwards, President Chen had referred to the threat of SARS more often than to any other NTS. ${ }^{53}$ He presented SARS as a threat in the framework of Taiwan's participation in the WHO, the key global player in pandemic response. Taipei was excluded and later denied membership in the WHO on polit-

Schools, Office of the President, 02.07.2008; Ma Ying-jeou, 總統接見日本東京大學教授若林正 丈一行 President Ma Meets Tokyo University Professor Mr. Masahiro Wakabayashi, Office of the President, 02.09.2008; Ma Ying-jeou, 總統出席97年「行政院暨所屬機關高階主管大陸工作研 習會」President Attends the 2008 ,Mainland Seminar of the Managerial Staff from the Executive Yuan and its Agencies", Office of the President, 28.12.2008; Ma Ying-jeou, op. cit., 19.5.2011.

${ }^{50} \mathrm{Ma}$ Ying-jeou，總統接見中國青年創業協會總會理監事及各縣市理事長 President Meets the Chairman of the Association of the Chinese Young Entrepreneurs and the Heads of Governments in Counties and Cities, Office of the President, 11.06.2009.

${ }^{51}$ J. Schwartz, Pandemic Responses in the Asia-Pacific: Risk and Opportunity in the PRC's International Relations, in: China's Challenges to Human Security: Foreign Relations and Global Implications, (ed.) G. Wu, Rutledge, London, New York, 2013, p. 262.

${ }_{52}$ M.G. Curley, J. Herington, The Securitization of Avian Influenza: International Discourses and Domestic Politics in Asia, ,Review of International Studies” 2011(37), p. 142.

${ }^{53}$ In the speeches available at the website of the Office of the President, Chen Shui-bian labelled as threats the following phenomena: SARS (also referring to SARS as avian influenza, infectious disease and pandemics) in 37 speeches, terrorism and terrorist attacks in 13 speeches, economic threats, including China rise and influx of cheap products - in 7 speeches and environmental degradation, interchangeably with environmental damage, global warming and sea-level rise in 4 speeches. 
ical grounds related to conflict with China. ${ }^{54}$ The WHO took the position that the PRC is the only legitimate representative of China and that Taiwan should interact with the organization via the PRC. In 1997, Taiwan started the campaign to rejoin the WHO as an observer (Lindemann 2014: 190). ${ }^{55}$ Still, Beijing successfully resisted all endeavours that could have increased Taiwan's participation in global affairs, including any form of participation in the UN and its specialized agencies. Taipei's efforts to join the organization were perceived as an attempt to push for independence, and therefore, Beijing considered them as a matter of national security. ${ }^{56}$ As a result of this interpretation of Taiwan's participation in IOs by the PRC, the states, which accepted the PRC's 'one China' principle, could not agree to Taipei's demands to join the organizations where statehood was a prerequisite for membership..$^{57}$ Therefore, the references to SARS as a threat were relevant to Chen's foreign policy mainly in the context of Taiwan's efforts to participate in the WHO/World Health Assembly (WHA). ${ }^{58}$ The president introduced SARS into the realm of politics as a threat by applying two argumentative schemes:

1) Taiwan's exclusion from the WHO/WHA as a threat to the health of people around the globe. President Chen's claims about the far-reaching consequences of Taiwan's exclusion from the international organization for the international community constituted continuation of the discourse promoted by his predecessor. President Lee Teng-hui argued that the absence of Taiwan from the WHO is unfair not only for Taiwanese people but also other countries, because Taiwan was able to contribute greatly to international society in the area of health. His argumentative strategy focused on Taiwan's willingness and ability to 'pay back' and 'contribute' to the international community. He stressed that Taiwan's expe-

${ }^{54}$ Taiwan was among the founding members of the United Nations (UN) and represented China in all major IGOs in the 1950s and 1960s, while the PRC held membership only in one (C.P. Li, Taiwan's Participation in Inter-Governmental Organizations: An Overview of Its Initiatives, „Asian Survey” 2006, July/August, (46,4), p. 597-614, 598). However, from the 1960s, support for the PRC's inclusion in the UN started to grow, finally leading to the change of international recognition in favour of the Mainland and its admission to the UN in 1971. In the following years, due to the Beijing's insistence to be recognized as the sole legal representative of China, Taiwan lost membership in most IGOs, including the UN specialized agencies. In 1972, it was expelled from the WHO and replaced by the People's Republic of China.

${ }^{55}$ B.A. Lindeman, Cross-Strait Relations and International Organizations: Taiwan's Participation in IGOs in the Context of its Relationship with China, Springer Fachmedien Wiesbaden, Wiesbaden 2014, p. 190.

${ }^{56}$ Jiang Zemin's Eight-point Proposal, „Taiwan Affairs Office of the State Council” PRC, 1995, 1, URL: <http://www.gwytb.gov.cn/en/Special/Jiang/201103/t20110316_1789198.htm> (access: 6.8.2015).

${ }^{57}$ Observership bids for Taiwan were proposed every year between 1997 and 2002 and all of them were rejected. In: B.A. Lindemann, op. cit., p. 191.

${ }^{58}$ Although the observership bids were inviting Taiwan to attend the WHA - the highest decision-making body of the WHO, still the public and politicians usually speak in general about joining or participation in the WHO. 
rience, know-how and exchange of information would improve the effectiveness and capabilities of international medical cooperation. ${ }^{59}$ Chen availed himself of this argumentation. He regretted that Taiwanese people could not contribute their expertise, experience, assistance, or skills to the global community and that their absence from international health institutions was not without impact on the health of people around the globe. The remarks about medical assistance and humanitarian aid flowing from Taiwan to countries in need served as proof of Taiwan's great willingness and abilities in this respect. Chen accentuated Taiwan's outstanding capabilities and experience in the area of medical health as well as strict application of international health care norms to demonstrate the value of Taiwan's potential inclusion and to create the impression that Taiwan was a responsible international actor with respect to health issues. ${ }^{60}$

Yet, President Chen not only advanced Lee's argumentation strategy but also revamped it by borrowing from the discourse portraying pandemics as threats to security. He particularly invoked this discourse by saying that diseases such as SARS constituted threats with global reach, and for this reason the coordinated response of all members of the international community was prerequisite for the effective combating of the disease.$^{61}$ This argumentative scheme allowed him to frame Taiwan's exclusion from WHO not only as an obstacle for Taipei to contribute to international healthcare system or international community, but foremost as a threat to third-world states and people around the globe. Chen claimed that the failure to incorporate Taiwan into the global disease response network created a soft spot or, in his words, a 'gap' in international disease identification, response, and control capabilities, and therefore, would undermine international efforts to fight pandemics.

${ }^{59}$ Lee Teng-hui, 總統今天接見參加第五屆世界臨床毒物學暨毒藥物防治中心聯盟大會 與會人士 Today the President Received the Participants of the Fifth Allied Congress of World Center of Clinical Toxicology and Poison Prevention, Office of the President, 11.11.1994; Lee Teng-hui, 總統接見第二屆亞太旅遊醫學國際會議外賓 President Received Foreign Guests Attending the Second International Conference on Asia-Pacific Travel Health,_Office of the President, 13.07.1998.

${ }^{60}$ As for example in Chen's 2006 Speech, where he stated: 'Just a few days ago, on May 15 , my country's Centres for Disease Control announced a voluntary early implementation of the International Health Regulations (IHR), adopted last year in the WHA, because we are willing to abide by international norms and to fulfil our responsibility as world citizens. Even though Taiwan is still excluded from the global epidemic prevention system, we nevertheless require from ourselves the highest standards.' Chen Shui-bian, op.cit., 19.05.2006; See also: Chen Shui-bian, 總統 應邀參加台灣團結聯盟一週年黨慶大會 President Chen Attends a Ceremony Marking the First Anniversary of the Taiwan Solidarity Union, Office of the President, 11.08.2002.

${ }^{61}$ Chen Shui-bian, 總統與日內瓦國際重要人士舉行越洋視訊會議 President Chen's Remarks at the Videoconference with Prominent European Opinion Leaders in Geneva, Office of the President, 19.05.2006. 
Health care, hygiene, health protection, and disease prevention do not have borders, so under the threat of SARS, avian flu or other infectious diseases, Taiwan cannot become the only gap in the global system of disease prevention ${ }^{62}$

2) Taiwan's exclusion from the WHO/WHA as a threat to the health of Taiwanese people. Chen stressed that when China replaced Taiwan at the WHO in 1972 , the island's health officials could not participate in all the activities of the organization and lost access to information and services provided to members of the WHO, such as data sharing, assessment of risk, early warning, surveillance, provision of virus samples, and equipment. As a consequence, in a crisis situation, Taiwanese people had been deprived of timely assistance and information, which were crucial for the effective response to pandemics. He claimed that:

After October 1971, when the Chinese Communist regime started to represent China in the United Nations, Taiwan's exclusion from the World Health Organization global health and prevention system as well as inability to obtain normal access to relevant information and technology created a gap in the monitoring of infectious diseases and prevention from the threat of biological terrorism. ${ }^{63}$

Chen underscored health-related aspects in order to convince the audience that Taiwan's participation in the WHO is legitimate for functional reasons and to downplay the struggle for diplomatic recognition. He described the problem of Taiwan's membership in the WHO as a 'purely health-care issue' ${ }^{64}$ Therefore his strategy was to remove Taiwan's participation in the WHO from the sphere of political or security to 'normal' or 'purely health-care issues'.

Chen went even further, arguing that since leaving the island out of the global health-care system deprived the Taiwanese people of help and assistance to which they should otherwise be entitled during the SARS crisis, the exclusion from the WHO amounted to denial of basic human rights for the Taiwanese people. He compared Taiwanese people who are "unable to obtain assistance from international health care system in a timely manner' when the 'international infectious disease wreaks havoc' across the island to 'orphans of the universal value of human rights' ${ }^{65}$

${ }^{62}$ Chen Shui-bian, 總統以錄影方式在國際自由聯盟 (LI) 第55屆大會開幕儀式發表談 話 President Chen Makes a Video Statement at the Opening Ceremony of 55th General Assembly of the Liberty International Union (LI), Office of the President, 16.05.2008.

${ }^{63}$ Chen Shui-bian, 總統接見海外僑界醫藥衛生人士回國參訪團 President Chen Meets with the Health Medicine Delegation of the Overseas Chinese, Office of the President, 15.08.2002.

${ }^{64}$ Chen Shui-bian, 總統赴台北國軍松山醫院參加SARS四週年紀念會活動 President Chen Attends the Fourth Anniversary Activities of SARS in Tri-Service General Hospital Songshan Branch, Office of the President, 04.05.2007.

${ }^{65}$ Chen Shui-bian, op.cit., 04.5.2007; See also: Chen Shui-bian, 總統參加「台灣與聯合 國」研討會開幕典禮 President Chen Addresses a Seminar on Taiwan's UN Bid, Office of the President, 16.06.2001. 
Chen employed functional rhetoric as a basis for his 'pragmatic', and later 'meaningful' approach to membership in the IOs. He described this approach during the videoconference with the international audience in Geneva as a 'humble' and 'sincere' pursuit of observer status instead of the formal membership in the WTO in order to 'avoid the disputes over sovereignty or politics and so as not to let our supporters face too much trouble. ${ }^{96}$

Here again, this approach towards Taiwan's participation in the IOs was neither new nor invented by Chen. Already president Lee Teng-hui made attempts to downplay the cross-Strait struggle for recognition of Taiwan's membership in the WHO and to convince the international community of the need of the island's participation. Lee made an effort to remove the China element form Taipei's drive to join the WHO by stressing that Taiwan should join 'non-political international organizations' for functional reasons. He claimed that, in the case of the WHO, the main reason was to provide health to Taiwanese people and to contribute to the work and expertise of the organization. Yet Lee's argument was vulnerable to the counterargument as to what constitutes an appropriate benchmark for assessing the political or non-political character of an IO, particularly in the situation when all Taiwanese foreign policy decisions, including those on international organizations, were judged against the background of political relations with China.

In contrast, references to the discourse on pandemics as threats to human security allowed Chen not only to remove the issue of Taiwan's WHO membership from the high politics of cross-Strait relations and national security, but foremost to portray it as pertaining to the area of low politics of health. This argumentative scheme enabled the president to avoid the trap of assessing the character of membership in the WHO and rendered Chen's pragmatic strategy more effective than that of his predecessor. This strategy won the support of the international community for Taiwan's 'meaningful' participation in the WHO and led to increased Taiwanese functional participation. A number of states, such as the US and Japan as well as the European Parliament and the NGOs, endorsed Taiwan's WHA observer status. ${ }^{67}$ This pragmatic approach, well received internationally, mainly due to the references to SARS as a threat, had also resonated domestically. The highly visible negative consequences of SARS in connection with the rhetoric about the consequences of Taiwan's exclusion from the WHO appealed to society, which, according to the opinion polls, showed overwhelming support for Taiwan's participation in the WHO.

${ }^{66}$ In addition, this year we have taken the most pragmatic approach, striving for the 'meaningful participation', which includes participation in the 'Global Outbreak Alert and Response Network', WHO's technical meetings and regional activities as well as in the mechanism of 'International Health Regulations' (IHR), all of which are based on the actual needs of the health care and epidemic prevention, not on the political considerations.' Chen Shui-bian, op.cit., 19.05.2006.

${ }^{67}$ B.A. Lindemann, op. cit., p. 225. 
Yet Chen and the DPP government were not consistent in this strategy of removing the China variable from the WHO issue. Despite attempts to stress that Taiwan's participation in the WHO was not about cross-Strait relations but about health, Chen did not entirely abandon the discourse, which was posing Taiwan's membership in the UN within the framework of the cross-Strait conflict. To the contrary, he frequently reminded his audience that it was China that should be blamed for Taiwan's difficulties in dealing with the SARS outbreak.

The Ma government responded to domestic and international expectations about Taiwan's participation in WHO with the policy seeking of observer status. President Ma took advantage of the already well-established discourse on functional participation pertaining to the pandemics as global threats to human security to set aside the sovereignty related issues as in the example below:

The United Nations specialized agencies, such as WHO, are all closely related to the well-being of the Taiwanese people, and the issue of sovereignty does not matter so much. Therefore, we can emphasize this aspect to the international community; the international community should be understanding and able to put themselves in our position, so to give Taiwan the opportunity for participation in international activities. ${ }^{68}$

Similar to his predecessor, he focused on meaningful participation in international organizations 'to improve the well-being of people', stressed that access to medical resources and information on an equal footing with other states is a matter of human rights of the Taiwanese people, and pointed to the Taiwanese contribution to the international community. ${ }^{69}$ Therefore, the discourse promoted by Chen set the direction for the argumentative strategy of the following president. At the same time, Ma was able to introduce changes to this discourse to align it with his overall strategy of the rapprochement with China, which was called 'flexible diplomacy' (活路外交 huolu waijiao). While Chen claimed that Taiwan's participation in IOs would facilitate improvement of relations with Beijing by providing additional channels for communication for both sides, Ma proposed the opposite logic, which considered the rapprochement with China as a prerequisite for Taiwan's participation in IOs. He explained to an audience at the National University of Tainan that the '[i]mprovement of relations across the Strait not only creates the dividend of peace but also helps us to expand the international space..$^{70}$ In 2009, after Taiwan had been invited to the WHO as an observer, Ma attributed this success to his new policy of 'flexible diplomacy', the main goal of which rested on the rapprochement with

${ }^{68}$ Ma Ying-jeou, 總統訪視外交部並闡述「活路外交」的理念與策略 President Ma visits the Ministry of Foreign Affairs and Elaborates on the Concept and Strategy of 'Flexible Diplomacy', Office of the President, 04.08.2008.

${ }^{69} \mathrm{Ma}$ Ying-jeou, 總統出席「『戰略暨國際研究中心』（CSIS ) 台灣關係法30週年研 討會」視訊會議 President Ma's Remarks at the Videoconference with the Centre for Strategic and International Studies, Office of the President, 22.04.2009.

${ }^{70}$ Ma Ying-jeou, op.cit., 19.05.2011. 
Beijing. This improvement in cross-Strait relations in turn, according to the president, won Taiwan trust among other allies and goodwill from the authorities in Mainland China. ${ }^{71}$

\section{CONCLUSION}

This article deals with the relevance of non-traditional threats to security for Taiwan's external relations. With this goal in mind, it analyses how the Taiwanese presidents Chen Shui-bian and Ma Ying-jeou frame discourse on NTS in public speeches. It finds that Taiwanese presidents most frequently apply two types of NTS in the context of international relations - threats of an economic nature and threats arising from the spread of pandemics. Both threats are congruent with the main threat to Taiwan's security - loss of sovereignty to the Mainland. It means that the Chinese threat to Taiwan has become multifaceted. It is no longer only about military danger.

The analysis of economic threats in the discursive practice of presidents demonstrates that economic exchange across the Taiwan Strait has never been only about the economy. In Taiwan, any interaction with China, regardless of its nature, is a matter of high politics, and for this reason Presidents Lee and Chen were able to link economic interaction with Beijing to national security. Both presidents referred to the economic threat of dependence on China in order to control and impose restrictions on economic interaction across the Strait. This discourse picturing Taiwan as exposed to economic threat from the Mainland became well established in the island's political discourse before 2008 and influenced the efforts of President Ma to liberalize cross-Strait exchanges. The signing of ECFA with China was controversial, as critics of this agreement were able to link economic cooperation with resonant narratives about Taiwan's security and China's threat. Nevertheless, Ma was able to position this agreement as not only legitimate but also as a highly desirable decision. He did this by locating the economic treaty within the narratives on globalization and economic interdependence, neoliberal inspired discourses promoting free trade, and narratives about the exclusion of Taiwan from international relations. He was very successful in drawing on particular representations of globalization and exclusion of Taiwan, which had already become popular during the previous presidency, to ensure that his proposal resonated with domestic audiences. Yet he was not successful in marginalizing the alternative narrative of the 'China threat'; therefore, a part of society remained critical of the economic agreement.

${ }^{71}$ Ma Ying-jeou, 總統主持高層會議就我國參與世界衛生大會及政府因應H1N1新型流 感作法發表談話 President Ma Delivers Statement on Taiwan's Participation in WHA and Government Measures to Combat New Strain of H1N1 Virus, Office of the President, 29.04.2009. 
Originally, the question of Taiwan's membership in the WHO was a highly political issue related to international relations regarding China's sovereignty, and all of Taipei's attempts to join the organization were perceived as threatening to Beijing's core national interests. In order to reframe the issue away from traditional security, Taiwan's presidents and political elites operationalized a discourse on the pandemics as NTS. They availed themselves of three main characteristics in this discourse. First, they exploited the element of this discourse according to which the referent object of security was not a state but health and stressed that the island's participation in the organization was about the security of Taiwanese people as well as of the international community. This in turn allowed Taiwanese politicians to switch from territorial sovereignty dominant in cross-Strait relations to human security in order to persuade the audience that the goal of Taiwan's effort to join WHO did not rest in offending China but in protecting the health of the people in Taiwan and abroad. Second, Presidents Chen and Ma took advantage of the practice where threats were regarded as concerns of low politics, in opposition to the high politics threats in the traditional model, and stressed that Taiwan's membership was not about politics but about 'health'. Third, they referred to the narrative of diseases as global problems that are inadvertent to national borders and necessitate global response as an argument for Taiwan's inclusion into the WHO. Yet President Chen was not consistent in this strategy of removing the issue of participation in the organization from the sphere of high politics, as he frequently blamed China for Taiwan's particular vulnerability during the outbreak of SARS. President Ma in turn was more coherent in utilizing the discourse treating pandemics as a threat to security mainly due to his efforts to demonstrate that he had no intention of offending China, that the relationship between Beijing and Taipei had greatly improved, and that Taiwan's participation in the WHO was a result of the consultation between both sides of the Strait.

This article highlights the opposite processes taking place when Taiwanese political elites refer to NTS. One the one hand, the discourse on economic threats to security limits Taiwan's participation in global trade. The labelling of issues of trade originally considered as of an economic nature as political, by linking them to the question of sovereignty, translates into the protectionist trade policies with respect to China. On the other hand, the new understanding of pandemics as a threat to security opens the door of opportunity for Taiwan's participation in international affairs, as it enables Taiwanese politicians to speak about the island's observership in WHO not as a political issue related to the question of sovereignty but as an issue of human security. 


\title{
NIETRADYCYJNE ZAGROŻENIA BEZPIECZEŃSTWA W DYSKURSIE TAJWAŃSKICH PREZYDENTÓW CHEN SHUI-BIANA I MA YING-JEOU'A
}

\begin{abstract}
Abstrakt. Podejście realistyczne jest nadal najczęściej stosowanym przy analizie polityki zagranicznej i bezpieczeństwa Tajwanu, a utrata terytorium i przyłączenie wyspy do Chin są uznawane za główne zagrożenia egzystencjalne. Niemniej jednak w dyskursie politycznym coraz częściej zwraca się uwagę na nietradycyjne zagrożenia dla bezpieczeństwa, takie jak bezpieczeństwo zdrowotne, czy bardziej ogólne bezpieczeństwo jednostki ludzkiej. Celem artykułu jest zbadanie procesu sekurytyzacji, czyli włączania nowych zagadnień do sfery bezpieczeństwa Tajwanu, poprzez analizę dyskursu politycznego dwóch prezydentów tajwańskich - Chen Shui-biana i Ma Ying-jeou'a.

Jak się okazuje, w politycznej retoryce Tajwanu coraz więcej miejsca poświęca się zagrożeniom ekonomicznym i zdrowotnym. Artykuł ukazuje, że poruszanie w dyskursie kwestii związanych z bezpieczeństwem ekonomicznym, prowadzi do ograniczenia udziału Tajwanu w światowym handlu. Powiązanie kwestii handlowych z politycznymi (problem suwerenności wyspy), przekłada się na protekcjonistyczną politykę handlową. Z drugiej strony, traktowanie pandemii jako zagrożenia dla bezpieczeństwa, pozwala tajwańskim politykom na ubieganie się o miejsce w Światowej Organizacji Zdrowia, niejako przyczyniając się do międzynarodowej legitymizacji wyspy i wzrostu jej znaczenie w stosunkach międzynarodowych.
\end{abstract}

Słowa kluczowe: nietradycyjne zagrożenia bezpieczeństwa (NTZ), polityka zagraniczna Tajwanu, Chen Shui-bian, Ma Ying-jeou, stosunki chińsko-tajwańskie 